\title{
WORLD WIRE WEB
}

\author{
Information at your fingertips.
}

\section{BY GARETH D JONES}

$\mathrm{T}$ here was a time when Boyd could have had all the information he desired at his fingertips. It became impossible to keep track of the sources of information that threatened to overwhelm everyday life. That was before the Pulse permanently wiped out all electronics worldwide. Only those like Boyd who were septuagenarians at least, could remember those times of information overload. With his memory failing intermittently, a sign of weakness that he couldn't afford, Boyd missed those days immensely.

He snapped his fingers to get the attention of Carmichael, a man of great size, low ambition and unquestioning loyalty. The burly man strode across the dimly lit lounge and leaned over Boyd's chair. His bald head reflected the yellowish light of a wall lamp.

"Get down to the Web office." Boyd's voice was still strong, but croaked perpetually. "I need a name."

Carmichael carefully pulled a black notebook and a gilt pen from the inner pocket of his suit. He stood patiently, pen in hand.

"Fifty years ago. Ran the dog track across the docks. Had a boy with a missing finger. His girlfriend - tall, brunette. I need to know what she was called. See if you can track her down."

Carmichael made brief notes in his book, then closed it and returned it to his pocket. As Carmichael left the room, Boyd shuffled a collection of papers on the oval table before him and prepared to meet his lieutenants.

The door into the Web office swung open slowly, accompanied by a tinkling bell, and Celia looked up from the counter at the imposing figure who entered. The chubby smile slid from her face. Smart suit, impassive face, shorn head - he worked for the Guv'nor, that was obvious. The man moved with a grace surprising for his size and pulled out a small notebook as he approached the counter. He tore out a page and placed it on the wooden surface, turned it to face Celia and pushed it across to her.

"The Guv'nor needs this information." There was no threat, no intimidation, but Celia knew that she should ask no questions.

She took a moment to read the neatly printed words, then turned to her workstation. Alongside a chunky black typewriter was a brass lever that protruded through a slot in the desk. A total of 12 notches adjoining the slot were neatly labelled with possible destinations for the telegram. She engaged the lever and moved it up into the slot labelled 'Council Offices'. Pulleys and ratchets connected her teletyper to the telegraph line that led from her roof to the Council Offices several miles away.

She began typing her message with the word 'Urgent'. Everyone wanted their message to be dealt with urgently, but operators room and stared out of the window. Celia turned back to her equipment, and willed the reply to arrive speedily. While she waited, she indulged in her regular daydream of working at one of the Web Hubs, where up to 100 destinations could be selected by a series of levers.

The reply came in 20 minutes, with information from the Land Registry and the Register Office, but with requests destined for elsewhere. Celia typed in the new destination and imagined her words racing along the lines to the North London Hub, and from there northward to the Lincoln Hub, then locally to the Lincolnshire Register Office.

By the time the request returned to Celia's 㝚 machine it incorporated the name of the son, born in Lincolnshire; a note from a North London hospital of a fatal stabbing almost

50 years past matching the name - and

a 'No Comment' from the Metropolitan Police.

The final comment was from an archivist at a North London newspaper. He had unearthed a report on the funeral, a picture of a small group of mourners, among them a tall brunette - a name.

Celia pulled the paper from the teletyper, circled the name and handed it over to Carmichael closer to two hours from when he had entered. He inclined his head politely and left without a word.

The meeting had gone well, although Boyd saw a predatory gleam in the eyes of some of his lieutenants. Carmichael arrived back as he was sipping the remains of a cup of tea. He took the paper and stared at the name. Annabelle. Yes, how could he have forgotten?

He pushed aside an assortment of papers and opened a large leather-bound notebook. A paragraph had been abandoned halfway down the page, and here Boyd took up the pen to continue his autobiography.

'Her name was Annabelle. When she ran off with the son of a dog-track owner, it started a feud that shook the whole borough. Her friend ran a boutique...'

"Carmichael, I need a name!"

Carmichael reached into his suit and once more pulled out his pen and notebook. $\rightarrow$ NATURE.COM

Discuss this story online at:

go.nature.com/ghenem
When the message was complete she pulled the paper from the machine and gave a copy to the unmoving Carmichael.

"How long?"

"Within the hour, usually."

"I'll wait."

Celia had been afraid he would say that. He took a seat in the corner of the waiting rhythm and tapped out the message across the telegraph wire.
Gareth D. Jones is an environmental scientist who also writes stories and drinks lots of tea. His stories have appeared in 40 publications. 